\title{
Influence of wilting on chemical and microbial parameters of grass relevant to ensiling
}

\author{
S. F. SPOELSTRA \& V. A. HINDLE
}

Institute for Livestock Feeding and Nutrition Research (IVVO) P.O. Box 160, NL 8200 AD Lelystad, Netherlands

Received 19 May 1989; accepted 23 August 1989

\begin{abstract}
Plots of perennial ryegrass underwent normal farm routine for making wilted silage. The grass was sampled periodically during, generally moist, wilting and analysed for chemical and microbial parameters. The average increase of the ammonium-nitrogen content was $5.8 \mathrm{~g}$ $\mathrm{kg}^{-1} \mathrm{~N}$ day-1. The crude fibre content also tended to increase during wilting $(6 \pm 4,3 \mathrm{~g}$ $\mathrm{kg}^{-1} \mathrm{DM}$ day $^{-1}$ ), though the correlation was poor. The sugar content of the grass and the in vitro digestibility decreased during wilting with $9 \pm 6.1 \mathrm{~g} \mathrm{~kg}^{-1} \mathrm{DM}$ day $^{-1}$ and $1.1 \pm 0.11 \%$ units day-1, respectively. Counts on rogosa agar increased on average $0.24 \pm 0.16$ logarithmic units (LU) $\mathrm{g}^{-1} \mathrm{DM} \mathrm{day}^{-1}$, on MRS agar $0.13 \pm 0.17 \mathrm{LU} \mathrm{g}^{-1} \mathrm{DM}$ day $^{-1}$. Enterobacteria enumerated on violet red bile glucose agar increased with $0.23 \pm 0.18 \mathrm{LU} \mathrm{g}^{-1} \mathrm{DM} \mathrm{day}^{-1}$. Inoculation by spraying the standing grass as an alternative to application on the forage harvester was investigated. In four separate trials the standing grass was sprayed with approximately $6.5 \mathrm{LU} \mathrm{g}^{-1} \mathrm{DM}$ of a silage inoculant containing Lactobacillus plantarum. During wilting the counts on Rogosa agar declined with $0.72 \pm 0.33$ $\mathrm{LU} \mathrm{g}^{-1} \mathrm{DM}_{\text {day }}{ }^{-1}$, and on MRS agar with $0.65 \pm 0.35 \mathrm{LU} \mathrm{g}^{-1} \mathrm{DM}^{\mathrm{day}}{ }^{-1}$, whereas the counts on the uninoculated control field increased with $0.17 \pm 0.19$ and $0.17 \pm 0.17 \mathrm{LU}$ $\mathrm{g}^{-1} \mathrm{DM}$ day $^{-1}$ for the rogosa and MRS media, respectively. It is concluded that inoculation of the standing grass is probably only useful in combination with a short wilting period.
\end{abstract}

Keywords: wilting, grass, silage, chemical composition, lactic acid bacteria

\section{Introduction}

The main goal of wilting a silage crop is to increase the dry matter (DM) content. The advantages are found in elimination of nutritional losses and environmental pollution by effluent. In addition elevated DM contents by restricting the fermentation reduce the in silo losses (Zimmer \& Wilkins, 1984) and eliminate butyric acid fermentation (Wieringa, 1958).

Drawbacks of wilting grass are the unavoidable field losses (Honig, 1980; van Bockstaele et al., 1980) and losses due to retardation of the regrowth of grass 
(Schukking \& Overvest, 1980). Field losses, being very much dependent on weather conditions have been estimated at $1-4 \%$ of the DM per day wilting period. Growth retardation is roughly equivalent to the length of the wilting period.

Animal intake of wilted grass silage is generally higher than of direct cut silage (Marsh, 1979; Deswysen, 1980), though it has been indicated that this higher intake is not always reflected in higher production (Steen \& Gordon, 1980).

In other words, wilting offers the advantage of restricting silage fermentation at the cost of field losses. But wilting also influences chemical and microbial composition of grass which could have negative consequences for silage fermentation and in the end for the feeding value of the silage.

These changes in composition could be important when wilting has to be carried out under weather conditions which do not allow a substantial increase in DM content. Under such conditions the wilting period has to be extended and field losses, losses due to growth retardation and possibly diminished ensilability, are not compensated for by reduced silage fermentation and absence of effluent.

The limited information available on this subject indicates that extensive protein degradation occurs during prolonged wilting (Carpintero et al., 1979; Anderson, 1983) and that the levels of lactic acid bacteria and enterobacteria increase during wilting (Weise, 1969).

The present paper aims to supplement the information available on the influence of the wilting period on the characteristics of grass.

\section{Materials and methods}

\section{Experimental}

\section{Wilting experiments}

For each experiment a plot of $12 \times 6 \mathrm{~m}$ was marked out in one of the permanent pasture fields of the institute. The pasture was used alternatively for grazing and mowing for silage. The fields received about $200 \mathrm{~kg} \mathrm{ha}^{-1}$ of inorganic nitrogen fertilizer in the spring followed by $80 \mathrm{~kg} \mathrm{~N} \mathrm{ha}^{-1}$ after grazing or cutting for silage.

These fields, with 3-3.5 t DM ha-1 of predominately perennial ryegrass, underwent routine farm practice for silage making (i.e. mowing with a disc mower and tedding once per day) during the wilting period. The plots were sampled by combining grab samples until in total a sample of about $15 \mathrm{~kg}$ was obtained, which was then subsampled by coring (diameter of the coring tube $40 \mathrm{~mm}$ ). After mixing the subsamples (in total about $2.5 \mathrm{~kg}$ ) in a 150 -l concrete mixer samples were taken for chemical and microbiological analyses.

The first sample was taken immediately after mowing and subsequently at least daily between 9.00 and 10.00 AM during the wilting period. To obtain an indication on the accuracy of the sampling method the results of 11 duplicate samples were compared. The standard error of the differences amounted to $7.2 \mathrm{~g} \mathrm{~kg}^{-1}, 5.2 \mathrm{~g}$ $\mathrm{kg}^{-1} \mathrm{DM}$ and $5.2 \mathrm{~g} \mathrm{~kg}^{-1} \mathrm{DM}$ for DM, ash and crude fibre, respectively.

The numbers of lactic acid bacteria and enterobacteria on the grass during wilting was followed and in addition the proximate composition, the ammonium and sugar 
Table 1. Weather conditions during the wilting experiments.

\begin{tabular}{llllll}
\hline Exp. & $\begin{array}{l}\text { Wilting } \\
\text { period } \\
\text { (d) }\end{array}$ & $\begin{array}{l}\text { Rain } \\
\left(\mathrm{mm} \mathrm{d}^{-1}\right)\end{array}$ & $\begin{array}{l}\text { Sun } \\
\left(\mathrm{hd}^{-1}\right)\end{array}$ & $\begin{array}{l}\text { Wind } \\
\left(\mathrm{m} \mathrm{s}^{-1}\right)\end{array}$ & $\begin{array}{l}\text { Temperature } \\
\left({ }^{\circ} \mathrm{C}\right)\end{array}$ \\
1 & 7 & 3.4 & 3.4 & & \\
2 & 3 & 11.8 & 6.5 & 3.4 & 13.2 \\
3 & 5 & 4.2 & 3.5 & 2.9 & 17.8 \\
4 & 8 & 7.9 & 3.8 & 3.6 & 12.8 \\
5 & 3 & 2.8 & 8.2 & 3.1 & 14.0 \\
6 & 2 & 0 & 7.4 & 1.5 & 20.6 \\
7 & 3 & 2.5 & 2.9 & 2.7 & 16.9 \\
8 & 3 & 2.3 & 2.5 & 3.4 & 13.0 \\
& & & & 3.1 & 9.8 \\
Mean & 4.3 & 4.4 & 4.8 & 3.0 & 14.8 \\
SEM $^{2}$ & 2.2 & 3.7 & 2.2 & 0.7 & 3.4 \\
\hline
\end{tabular}

1 Average of 24 hours means.

2 Standard error of the mean.

contents and the in vitro digestibility were estimated.

The experiment was repeated 8 times during the years 1983-1985 throughout the season.

Data on the weather conditions were obtained from a weather station at $12 \mathrm{~km}$ distance, except for the rainfall which was recorded on site (Table 1).

Spraying the standing grass with inoculant

In four separate trials, lactobacilli were sprayed on the standing grass just before mowing. Spraying was done with Empas horticulture equipment at a rate of 2001 $\mathrm{ha}^{-1}$ of an inoculant suspension containing about 8 logarithmic units (LU) $\mathrm{ml}^{-1}$. The interval between spraying and sampling after mowing did not exceed $30 \mathrm{~min}$.

The inoculant applied was Biomax SI (Chr. Hansen Biosystems, Copenhagen) containing at least $10.7 \mathrm{LU}$ per gram of a freeze-dried Lactobacillus plantarum strain.

The experimental design was similar to that described above with exception that two control and two treated plots were marked in the same field.

\section{Chemical analyses}

Proximate analyses were performed as outlined by van Es \& van der Meer (1981). Sugar analysis was carried out according to the Dutch norm (Anonymus, 1974).

Organic matter digestibility of the grass was estimated by the in vitro technique of Tilley \& Terry (1963) as adapted at IVVO by van der Meer (unpublished). The results were corrected to in vivo values by using standard grass samples of known in vivo digestibility as estimated in digestibility trials with wethers fed at maintenance. 


\section{Microbiological procedures}

Extracts of grass were prepared by treating $30 \mathrm{~g}$ to which $270 \mathrm{~g}$ of deionized water had been added for $5 \mathrm{~min}$ in a Stomacher (Seward Laboratory, London). From the extract a decimal dilution series was prepared in sterile quarter-strength Ringer solution.

Per sample two dilution series were prepared and Petri dishes inoculated in duplicate.

Enterobacteria were enumerated on layered pour plates of violet red bile glucose agar (VRB; Oxoid). Colonies were counted after incubation for 2 days at $30^{\circ} \mathrm{C}$.

Lactic acid bacteria were counted on layered pour plates of MRS agar (Oxoid) and rogosa agar (Difco). Colonies were counted after 3 days incubation at $30^{\circ} \mathrm{C}$.

\section{Results}

\section{Wilting experiments}

Table 2 gives for each individual experiment the relationships found by linear regression between the various parameters studied and the wilting period.

During Experiments 5, 6 and 7, little or no rain fell. In these experiments the DM contents during wilting increased on average with $116 \mathrm{~g} \mathrm{~kg}^{-1}$ day $^{-1}$. In the other experiments, wilting had no systematic influence on the DM contents due to rainfall.

No relationships were found between ash or nitrogen contents and the length of the wilting period.

The ammonium content of the grass throughout the wilting period was measured in three experiments only. In these experiments the grass received from 3.4-11.8 mm of rain per day. The ammonium content increased on average with $5.8 \mathrm{~g}$ ammonium- $\mathrm{N} \mathrm{kg}^{-1} \mathrm{~N}$ day $^{-1}$.

Due to respiration and other losses it was expected that the crude fibre content would increase during wilting. In four experiments an increase was found (mean $6 \pm 4.3 \mathrm{~g} \mathrm{~kg}^{-1} \mathrm{DM} \mathrm{day}^{-1}$ ), though the correlation coefficients of the regression lines were low.

The sugar content of the grass decreased in all experiments during wilting. This with the exception of Experiment 8 where grass was wilted at $10^{\circ} \mathrm{C}$, which showed increased sugar contents. When only the experiments having a regression line with significant correlation coefficients are considered, the average reduction in sugar content amounts to $9 \pm 6.1 \mathrm{~g} \mathrm{~kg}^{-1} \mathrm{DM}$ day-1. In these experiments this was equivalent to an average daily reduction of $8 \%$.

In 6 out of 8 experiments the reduction of the in vitro digestibility of the organic matter could be described by linear regression. The average daily reduction amounted to $1.1 \pm 0.11$ units day-1, equivalent to $1.3 \%$ daily reduction.

\section{Epiphytic microbiota}

Results are given in Table 3 . The number of lactic acid bacteria counted directly af- 
INFLUENCE OF WILTING ON GRASS

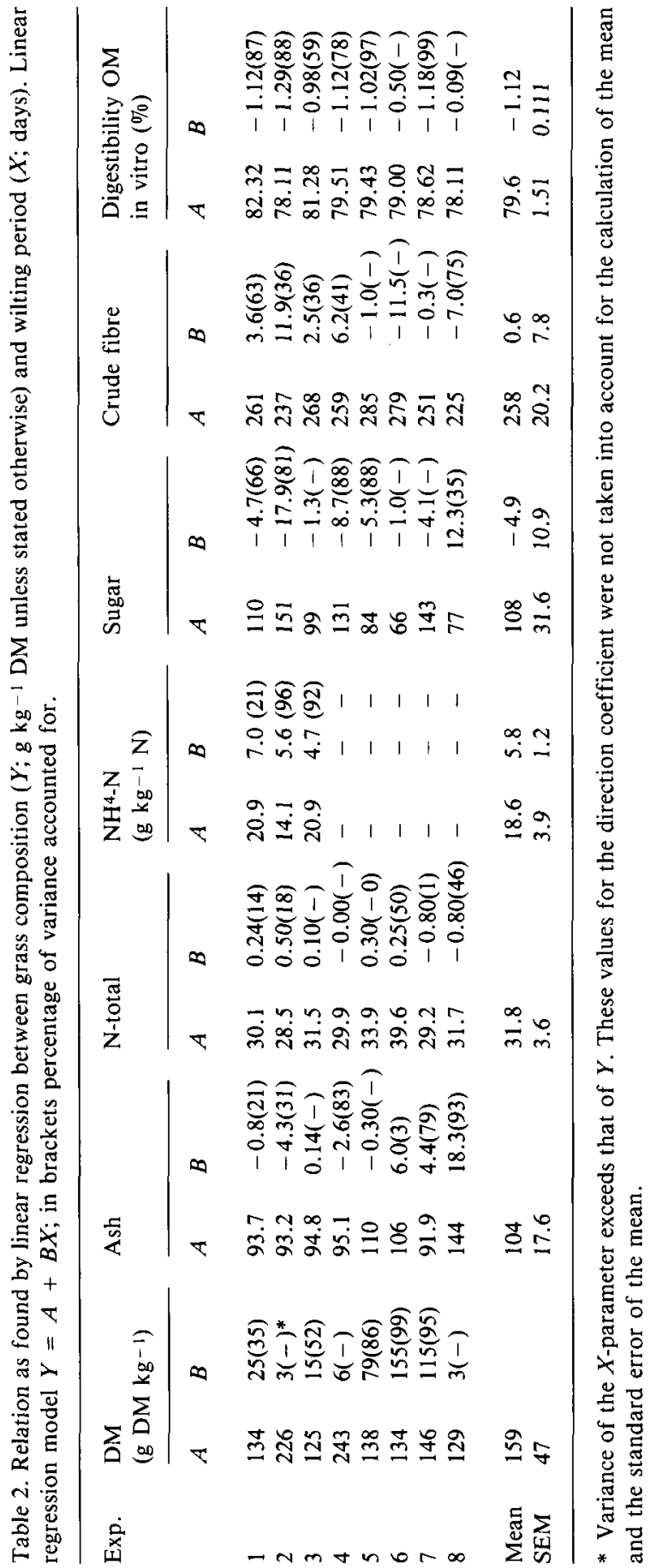

Netherlands Journal of Agricultural Science 37 (1989) 
Table 3. Initial numbers ( $\left(\mathrm{U} \mathrm{g}^{-1} \mathrm{DM}\right)$ and increase ( $\mathrm{LU} \mathrm{g}^{-1} \mathrm{DM}$ day-1) (with the correlation coefficient of the line obtained by linear regression in brackets) of lactic acid bacteria and enterobacteria on grass during the wilting period.

\begin{tabular}{|c|c|c|c|c|c|c|}
\hline \multirow[t]{2}{*}{ Exp. } & \multicolumn{3}{|c|}{ Initial count } & \multicolumn{3}{|c|}{ Increase by wilting } \\
\hline & $\operatorname{Rog} 1$ & MRS2 & $\mathrm{VRB}^{3}$ & Rog & MRS & VRB \\
\hline 1 & 4.24 & 4.38 & 6.41 & $0.21(0.91)$ & $0.23(0.81)$ & $0.23(0.93)$ \\
\hline 2 & 2.64 & 4.84 & 6.54 & $0.41(0.70)$ & $0.14(0.63)$ & $0.22(0.92)$ \\
\hline 3 & 2.86 & 4.10 & 6.49 & $0.41(0.99)$ & $0.08(0.67)$ & $0.20(0.89)$ \\
\hline 4 & 2.69 & 3.69 & 7.13 & $0.21(0.95)$ & $0.26(0.95)$ & $0.16(0.94)$ \\
\hline 5 & & 4.62 & 6.42 & & $0.38(0.71)$ & $0.51(1.00)$ \\
\hline 6 & 4.35 & 5.31 & 6.60 & $0.35(0.49)$ & $-0.03(0.07)$ & $0.35(0.99)$ \\
\hline 7 & 4.54 & 5.52 & 6.90 & $0.07(0.46)$ & $-0.14(0.76)$ & $-0.11(0.94)$ \\
\hline 8 & 3.61 & 4.13 & 6.78 & $0.02(0.29)$ & $0.09(0.50)$ & $0.26(0.75)$ \\
\hline Mean & 3.56 & 4.57 & 6.66 & 0.24 & 0.13 & 0.23 \\
\hline SEM & 0.83 & 0.68 & 0.26 & 0.16 & 0.17 & 0.18 \\
\hline
\end{tabular}

1 Rog, lactobacili counted on rogosa agar.

2 MRS, lactic acid bacteria counted MRS agar.

3 VRB, enterobacteria counted on VRB agar.

ter mowing on MRS agar averaged 4.6 $\mathrm{LU} \mathrm{g}^{-1} \mathrm{DM}$. The average number as counted on rogosa agar was ten times lower. The average initial level of enterobacteria amounted to $6.66 \mathrm{LU} \mathrm{g}^{-1} \mathrm{DM}$.

For the individual experiments the increase of the numbers during wilting was expressed in an equation found by linear regression.

The mean correlation coefficient of the regression line was $0.79 \pm 0.206$.

The average daily increase of the epiphytic groups evaluated, as based on the direction coefficients of the regression lines, amounted to $0.24 \pm 0.16,0.13 \pm 0.17$ and $0.23 \pm 0.18 \mathrm{LU} \mathrm{g}^{-1} \mathrm{DM}^{\mathrm{day}^{-1}}$ for counts on rogosa, MRS and VRB agars, respectively.

\section{Spraying of the standing grass}

Results are given in Table 4. The inoculation level by spraying the standing grass ranged in the different experiments from 5.8-7.0 LU $\mathrm{g}^{-1} \mathrm{DM}$, as was found by enumeration samples taken directly after mowing. During wilting the number of lactobacilli on the inoculated grass decreased. Counts on MRS and rogosa agars decreased with $0.65 \pm 0.353$ and $0.72 \pm 0.329 \mathrm{LU} \mathrm{g}^{-1} \mathrm{DM}^{\mathrm{day}}{ }^{-1}$, respectively. On the uninoculated control plots these counts increased during wilting.

\section{Discussion}

It is well documented that wilting under favourable weather conditions gives limited field losses and can be part of a very effective system of silage making (Zimmer \& 
Table 4. Initial numbers ( $\left.\mathrm{LU} \mathrm{g}^{-1} \mathrm{DM}\right)$ and increase ( $\mathrm{L} \mathrm{g}^{-1} \mathrm{DM}$ day $\left.{ }^{-1}\right)$ with the correlation coefficient of the line obtained by linear regression in brackets) of lactic acid bacteria and enterobacteria on untreated or field-sprayed grass.

\begin{tabular}{|c|c|c|c|c|c|c|}
\hline \multirow[t]{2}{*}{ Exp. } & \multicolumn{3}{|c|}{ Initial count } & \multicolumn{3}{|c|}{ Increase by wilting } \\
\hline & $\operatorname{Rog} 1$ & MRS $^{2}$ & VRB $^{3}$ & Rog & MRS & VRB \\
\hline \multicolumn{7}{|c|}{ Untreated } \\
\hline 1 & 3.32 & 4.40 & 6.66 & $0.02(0.12)$ & $0.21(0.37)$ & $0.07(0.22)$ \\
\hline 2 & 4.88 & 4.78 & 7.63 & $0.43(0.86)$ & $0.38(0.79)$ & $-0.23(0.95)$ \\
\hline 3 & 4.55 & 5.53 & 6.91 & $0.22(0.85)$ & $-0.02(0.12)$ & $-0.29(0.79)$ \\
\hline 4 & 3.60 & 4.12 & 6.77 & $0.02(0.26)$ & $0.09(0.50)$ & $0.26(0.75)$ \\
\hline Mean & 4.09 & 4.69 & 6.99 & 0.17 & 0.17 & -0.05 \\
\hline SEM & 0.75 & 0.61 & 0.44 & 0.196 & 0.171 & 0.259 \\
\hline \multicolumn{7}{|c|}{ Field-sprayed } \\
\hline 1 & 5.81 & 5.79 & 6.61 & $-1.19(0.98)$ & $-1.17(0.95)$ & $0.20(0.65)$ \\
\hline 2 & 7.09 & 6.98 & 6.77 & $-0.60(0.92)$ & $-0.46(0.87)$ & $0.24(0.45)$ \\
\hline 3 & 6.21 & 6.25 & 7.17 & $-0.65(0.87)$ & $-0.58(0.67)$ & $-0.28(0.84)$ \\
\hline 4 & 6.33 & 6.33 & 6.45 & $-0.43(0.99)$ & $-0.40(0.97)$ & $0.36(0.89)$ \\
\hline Mean & 6.36 & 6.34 & 6.75 & -0.72 & -0.65 & 0.25 \\
\hline SEM & 0.535 & 0.49 & 0.309 & 0.329 & 0.353 & 0.076 \\
\hline
\end{tabular}

1 Rog, lactobacili counted on rogosa agar.

2 MRS, lactic acid bacteria counted MRS agar.

3 VRB, enterobacteria counted on VRB agar.

Wilkins, 1984). However, under adverse weather conditions the wilting period must be extended because the target DM content is not reached.

The experiments conducted were, with a few exceptions, carried out under weather conditions which did not result in an increase of the DM contents. The results of these trials are considered to be representative for weather conditions less suitable for making wilted silage.

It was found that under these weather conditions the ammonium- $\mathrm{N}$ content of the grass increased with about $6 \mathrm{~g} \mathrm{~kg}^{-1} \mathrm{~N}$ day-1 wilting, which is equal to the $20-30 \mathrm{~g}$ ammonium $-\mathrm{N} \mathrm{kg}^{-1} \mathrm{~N}$ mentioned in the literature after 4-6 days of moist wilting (Carpintero et al., 1979; Anderson, 1983). During wilting grass protein is decomposed by plant enzymes to free amino acids and probably amides (Kemble \& MacPherson, 1954). The ammonium formed on the field originates from the further degradation of these products. It is not clear to what extent plant enzymes or the epiphytic microbiota are involved in ammonium formation during wilting.

The sugar content relative to the buffering capacity has been found to be the most important single factor for preservation of a low DM crop (Weissbach et al., 1974). During wilting the daily drop in sugar content averaged $6 \mathrm{~g} \mathrm{~kg}^{-1} \mathrm{DM}$. The impres- 
sion was that the larger losses occurred when rain fell on the crop with DM contents over about $350 \mathrm{~g} \mathrm{~kg}^{-1}$. The obtained data suggest that the losses of sugar are rather limited when grass is wilted under moist conditions. However, interpretation is difficult because the measured loss is probably the resultant of respiration and sugar release from polysaccharide hydrolysis (Dewar et al., 1963) and of some photosynthesis in the grass after cutting.

The losses occurring during wilting consist of highly digestible material (Honig, 1980). As a consequence the crude fibre content is expected to increase and the digestibility to decrease. No relationship was found between wilting period and the crude fibre content. The daily change in crude fibre content was in the same order of magnitude as the combined errors of sampling and analysis.

It is also conceivable that the composition of crude fibre changes during wilting possibly as the result of enzymatic polysaccharide breakdown during wilting. The in vitro digestibility declined during wilting and appeared to be a better parameter to estimate the effect of wilting on the feeding value of the grass than the crude fibre content.

The number of lactic acid bacteria added as inoculant relative to the epiphytic population appears to be one of the parameters determining whether inoculation of grass for silage is succesful (Pahlow, 1987). In the present investigation the level of lactic acid bacteria increased during wilting, indicating an increasingly lower efficacy of inoculation. Similar results have been reported by Weise (1969) and Muck (1989) for wilting under moist conditions. When high $(>50 \%)$ DM contents are reached these authors noticed rather a drop in counts. It should be noted that that in the present study only the effects of wilting and tedding were taken into account, whereas other workers counted the microbiota also after raking and passing through a forage harvester, which often gives a high rise in counts of lactic acid bacteria (Fenton, 1987; Muck, 1989; Ruser, 1989).

As stated above the presented results for the formation of ammonium and the development of the epiphytic microbiota during moist wilting are in line with data obtained elsewhere for different crops and climatic conditions. For the other parameters a basis for comparison is lacking.

Inoculation by spraying the inoculant on the standing grass could be an alternative to the usual application on the forage harvester. This could be a useful approach in those situations where it is difficult to obtain an even distribution of an additive as is for example the case with a forage pick-up wagon. A high inoculation level was achieved in the trials, but during wilting the numbers of lactic acid bacteria declined rapidly. So there seems to be a contradiction between this observation and the increase of the epiphytic microbiota during wilting. It has been demonstrated that growth of lactobacilli on grass takes place at those places where the stem or leave is damaged an where substrate becomes available (Stirling \& Whittenbury, 1963). By spraying on standing grass the inoculant is probably mainly added to the undamaged plant surface and hence will suffer from a lack of substrate. The results of the experiment suggest that inoculation just before or at mowing may be an alternative only in combination with a short wilting period. This was confirmed in experiments with laboratory silages (Spoelstra \& Hindle, unpublished). 
Also the counts of enterobacteria on the grass increased during wilting. Enterobacteria are dominating the fermentation directly after ensiling. Because of the inefficient fermentation their activity should be limited. But the significance of enterobacteria on the grass for the silage is not clear. Spoelstra (1987) estimated in a limited number of experiments that the number of enterobacteria on grass developing after ensiling is about two orders of magnitude lower than the total number of enterobacteria on the grass at ensiling.

\section{References}

Anderson, R., 1983. The effect of extended moist wilting and formic acid additive on the conservation as silage of two grasses differing in total nitrogen content. Journal of the Science of Food and Agriculture 34: 808-818.

Anonymus, 1974. Test methods for feeding stuffs. Determination of reducing sugar, crude total sugar, saccharose and lactose (NEN 3571), pp. 1-10. Nederlands Normalisatie Instituut, Rijswijk, Netherlands.

Carpintero, C. M., Henderson, A. R. \& P. McDonald, 1979. The effect of some pre-treatments on proteolysis during the ensiling of herbage. Grass and Forage Science 34: 311-315.

Deswysen, A., 1980. Influence de la longueur des brins et de la concentration en acides organiques des silages sur l'ingestion volontaire chez les ovins et les bovins. Ph. D. thesis, Louvain, $254 \mathrm{pp}$.

Dewar, W. A., P. McDonald \& R. Whittenbury, 1963. The hydrolysis of grass hemicelluloses during ensilage. Journal of the Science of Food and Agriculture 14: 411-417.

Es, A. J. H. van \& J. M. van der Meer, 1981. Methods for prediction the energy and protein value of feeds for farm animals. Institute for Livestock Feeding and Nutritiom Research (IVVO), Lelystad, $106 \mathrm{pp}$.

Fenton, M. P., 1987. An investigation into the sources of lactic acid bacteria in grass silage. Journal of Applied Bacteriology 62: 181-188.

Honig, H., 1980. Mechanical and respiration losses during pre-wilting of grass. In: C. Thomas (Ed.), Forage conservation in the 80's, p. 210-213. Proceedings Occasional Symposium No. 11. British Grassland Society.

Kemble, A. R. \& H. T. MacPherson, 1954. Liberation of amino acids in perennial rye grass during wilting. Biochemical Journal 58: 46-49.

Marsh, R., 1979. The effects of wilting on fermentation in the silo and on the nutritive value of silage. Grass and Forage Science 34: 1-10.

Muck, R. E., 1989. Initial numbers on Lucerne prior to ensiling. Grass and Forage Science 44: 19-25.

Pahlow, G. \& B. Dinter, 1987. Silage inoculation and epiphytic lactic acid bacteria of forage crops. FEMS Microbiology Reviews 46: 89.

Ruser, B., 1989. Das Vorkommen von Laktobakterien auf Futterpflanzen. Landbauforschung Völkenrode 39: 32-39.

Schukking, S. \& J. Overvest, 1980. Direct and indirect losses caused by wilting grass. In: C. Thomas (Ed.) Forage conservation in the 80's, p. 210-213. Proceedings Occasional Symposium No 11. British Grassland Society.

Spoelstra, S. F., 1987. Degradation of nitrate by enterobacteria during silage fermentation of grass. Netherlands Journal of Agricultural Science 35: 43-54.

Steen, R. W. J. \& F. J. Gordon, 1980. The effect of type of silage and level of concentrate supplementation of fered during early lactation on total lactation performance of January/February calving cows. Animal Production 30: 341-354.

Stirling, A. C. \& R. Whittenbury, 1963. Sources of lactic acid bacteria occurring in silage. Journal of Applied Bacteriology 26: 86-90.

Tilley, J. M. \& R. E. Terry, 1963. A two stage technique for the in vitro digestion of forage crops. Journal of the British Grassland Society 18: 86-90. 


\section{S. F. SPOELSTRA AND V. A. HINDLE}

Van Bockstaele, E. J., T. J. Behaeghe \& A. E. de Baets, 1980. Studies on the field losses of wilting grass. In: C. Thomas (Ed.) Forage conservation in the 80's, p. 205-209. Proceedings Occasional Symposium No 11. British Grassland Society.

Weise, F., 1969. Einfluss des epiphytischen Keimbesatzes auf den Gärverlauf. In: Proceedings of the third general meeting of the European Grassland Federation (Braunschweig), p. 221-227. Gesellschaft für Pflanzenbauwissenschaften, Frankfurt am Main.

Weise, F. \& H. Honig, 1975. Einfluss unterschiedlicher Vorwelkzeiten auf den Gärverlauf bei Wiesenschwingel. Das Wirtschaftseigene Futter 21: 10-24.

Weissbach, F., L. Schmidt \& E. Hein, 1974. Method of anticipation of the run of fermentation in silage making based on the chemical composition of green fodder. In: Proceedings 12th International Grassland Congress (Moscow), Vol. 3, p. 663-673.

Wieringa, G. W., 1958. The effect of wilting on butyric acid fermentation in silage. Netherlands Journal of Agricultural Science 6: 204-210.

Zimmer, E. \& R. J. Wilkins, 1984. Efficiency of silage systems: a comparison between unwilted and wilted silages (Eurowilt). Landbauforschung Völkenrode. Sonderheft 69, 88 pp. 